\title{
The Dating and Provenance of Bologna, Civico Museo Bibliografico Musicale, MS Q 19
}

ROBERT NOSOW

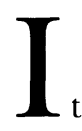

has now been more than twenty years since the publication of Edward E. Lowinsky's edition of the Medici Codex. ${ }^{1}$ The theses presented by Lowinsky concerning the Medici Codex and concerning Bologna, Civico Museo Bibliografico Musicale, MS Q 19, "the Rusconi Codex," have occasioned much comment and stimulated substantial new research. Most of the discussion concerning $Q 19$ has been tied to the hypotheses set out by Lowinsky, and less has been said about the general problems presented by the manuscript. $^{2}$ In view of the recent publication of the manuscript in the Garland series of Renaissance Music in Facsimile, the time is ripe to synthesize some of the subsequent research findings-mostly published as reviews of or responses to Lowinsky - and to add new evidence that may present a solution to the problems of dating and provenance. 3

The question of the provenance of $Q 19$ has aroused a great deal of debate not only because of the importance of the collection, but because it offers so many different clues. I will deal briefly with the relevant aspects of physical structure and organization. The manuscript comprises 211 paper folios, with 7 preliminary folios, 202 folios with original numeration in ink on the top right hand corner of each

1 Edward E. Lowinsky, ed., The Medici Codex of 1518 (Chicago and London, 1968), published as vols. III-V of Monuments of Renaissance Music, 8 vols. to date, general editor Edward E. Lowinsky.

2 Ibid. Lowinsky's discussion of Bologna $Q 19$ is found on pp. 52-6o.

3 Jessie Ann Owens, Introduction to Bologna Civico Museo Bibliografico Musicale, MS. Q19 ("The Rusconi Codex"), facsimile edition (New York and London, 1988), published as vol. I of Renaissance Music in Facsimile, 29 vols., ed. Howard Mayer Brown et al., pp. v-xvi. A bibliography is found on p. vii. 
recto, and 2 final, unnumbered folios. 4 The initial folio [o] apparently was added to the manuscript upon restoration, as was folio [204].5 The folios with original numeration are ruled by a double rastral on both recto and verso; the second rastral is slightly smaller than the first, and every other staff is also partially indented. Each of these pages has ten five-line staves. The main body of the manuscript (the enumerated folios) comprises a regular series of quaterns, except for the last gathering, which is a quintern. ${ }^{6}$

Three watermarks have been identified in the manuscript. The paper used for the main body of $Q 19$, as well as the last four preliminary folios (III-VI, labelled hereafter with Roman numerals) has a uniform watermark, an anchor inscribed in a circle. 7 The watermark has been measured by Lewis Lockwood, who concludes that it is "quite close" to the watermarks of a manuscript in Belgrade dated $15^{14} .^{8}$ This type of watermark was used by Venetian paper manufacturers in the first two decades of the sixteenth century, and the paper used in the main body of $Q 19$ undoubtedly originated in the Veneto. The separate sheet that follows the main corpus [203] has an unidentified watermark, a cardinal's hat with a letter "P" below.9 Folio II also has a distinct watermark, the letters " $L \mathrm{C}$ " surmounted by a cross, which Lowinsky identifies with Briquet No. 9553, found in Saló, $15^{2} 5^{10}$

By scholarly consensus, $Q 19$ is the work of a single scribe. The text is written in an italic script that Lockwood calls "angular, thin, [and] slanted." ${ }_{11}$ The scribe took some pains with his work, as is shown, for example, by the erasure on folio 46 recto, as well as the careful layout of the music. There are no decorated initials, although the shape of the initials goes through some standard variations. ${ }^{12}$ The

4 Ibid., vi.

5 Ibid., vi.

6 Ibid., vi-vii.

7 Edward E. Lowinsky, "On the Presentation and Interpretation of Evidence: Another Review of Costanzo Festa's Biography," Journal of the American Musicological Society XXX/1 (1977), 120 n. $5^{6 \text {, and } 122 .}$

8 Lewis Lockwood, "Jean Mouton and Jean Michel: New Evidence on French Music and Musicians in Italy, 1505-1520," Journal of the American Musicological Society XXXII/2 (1979), 239.

9 Lowinsky, "On the Presentation and Interpretation of Evidence," p. 122 n. 57.

10 Ibid.

1 Lockwood, "Jean Mouton and Jean Michel," p. 236 n. 107.

12 Eight decorated initials have, however, been cut out from other manuscripts and pasted in. There appears to be no pattern of placement with respect to either composer or liturgical calendar. On the other hand, Mouton's "Salva nos Domine," ff. $22^{\prime}-23$, is the first work in the manuscript beginning with "S," Renaldo's "Illuminavit eum," ff. $23^{\prime}-25$, is the first "I," Jacquet's "Sufficiebat nobis/Mon souvenir" is the next 
notes were written first, as indicated by their generally even spacing, and the text was underlaid beneath them. The music hand lacks the polish of a presentation manuscript such as the Medici Codex. It exhibits two distinct manners. In the main corpus of the manuscript, the noteheads are generally square and of uniform size. Outside the main corpus - in the preliminary section, folios I-VI, and at the end, folios $202^{\prime}-\left[203^{\prime}\right]$ - the music hand is cursive, with a single stroke for both notehead and stem. Here the noteheads are round and the stems are short and often slanted. Minims with downward stems have distinctive, half-moon noteheads drawn to the left of the stem. Where there are no staff lines, new ones are drawn freehand, or added with a new, smaller rastrum (folio $\mathrm{VI}^{\prime}$ ).

Bologna $Q 19$ is a choirbook, with typical placement of cantus and tenor on the verso of every opening, and alto and bass on the recto. The latest, authoritative inventory lists ninety-six works, the great majority for four voices. ${ }^{13}$ Pieces calling for larger forces are so designated in the manuscript index (folios IV'-VI). The main body of the manuscript was compiled according to a simple plan; it begins with three untexted settings of the cantus firmus "Fors seullement" 94 (with another on folio $9^{\prime}$ ), proceeds to the great body of motets, and closes with settings of the Mass ordinary and the Magnificat, interspersed with miscellaneous works. Among the motets, there are three sections that appear to be grouped by text: folios $23^{\prime}-55$ contain largely orationes, or prayers addressed to Jesus, the saints and the Virgin Mary; folios $55^{\prime}-84$ carry texts predominantly from feasts of the Temporale; and folios $111^{\prime}-31$ contain a cluster of psalm settings. ${ }^{14}$

Table 1 shows the contents of the preliminary gatherings of the codex. The verso of folio I carries the heading:

\author{
isi8/ adi. io. đ zugno/ \\ Seb. festa.
}

\footnotetext{
"S" after that, and so on. The pattern is consistent with the efforts of a dilettante to beautify the manuscript. One exception, the initial for Renaldo's "Ave sanctissima Maria," ff. $5^{\mathrm{o}^{\prime}}-5^{2}$, comes from a different manuscript than the other seven initials. See University of Illinois Musicological Archives, The Census-Catalogue of Manuscripts of Polyphonic Music, 1400-1550, 5 vols. (Neuhausen-Stuttgart: American Institute of Musicology, 1979-88), I, 73 .

13 Owens, Introduction, ix-xiii.

${ }^{14}$ On use of the words "orayson" and "oratio," see Lockwood, "Jean Mouton and Jean Michel," pp. 225, 228, 228 n. 86. For a discussion of the texts, see Lowinsky, "On the Presentation and Interpretation of Evidence," p. 123 and 123 notes $58-67$.
} 
TABLE 1

\section{Bologna Q 19, Preliminary Folios}

$\begin{array}{ll}{[\text { o]-I }} & \text { Blank } \\ \text { I'-II } & \text { Sebastiano Festa, "Angele Dei" } \\ \text { II' } & \text { Library mark } \\ \text { III } & \text { Monogram, Silhouette } \\ \text { III'-IV } & \text { Jean Mouton, "Moriens lux amatissima" } \\ \text { IV'-VI } & \text { Index } \\ \text { VI'-1 } & \text { Pierre Moulu, "Jay" }\end{array}$

A motet, "Angele Dei," opens the manuscript and, as mentioned previously, is copied freehand, without a rastral. Folios I and II are physically separate from the rest of the manuscript, not only in having different paper, but in that they are attached to the quatern following, folios III-VI, by means of pasting and paper strips. ${ }^{15}$ The verso following "Angele Dei" $\left(\mathrm{II}^{\prime}\right)$ is blank except for what may be a library shelf mark, "F. VI," centered on the page. Lewis Lockwood notes that it does not appertain to the Civico Museo, but as yet it remains unidentified. ${ }^{16}$ On the opposite page, folio III recto, are two emblems that might give clues concerning the origins of $Q$ 19. The first is a cartouche, or monogram, drawn in scribe's ink. It frames two initials, "D P," joined by a line. Perpendicular to this line rises another, which forms the base of a barbed cross. ${ }^{17}$ On either side of the cartouche is a trumpet-like figure inscribed with a small "O." Lowinsky avers that the initials stand for Diane de Poitiers, mistress of Henry II of France, and that the manuscript is of French provenance. ${ }^{18}$ He supports his assertion by pointing to the character of the second emblem, a silhouette of a kneeling stag chained to a tree. ${ }^{19}$ Other writers, however, notably Ludwig Finscher, dispute this claim, both on iconographical grounds and because the silhouette, made of paper, has been pasted on to the page. ${ }^{20}$ It may not have been placed there until the eighteenth century, when such silhouettes first became popular. The first emblem, however, by virtue of its character, its central placement on

${ }_{15}$ Owens, Introduction, vi. See also Martin Staehelin, Review of Edward E. Lowinsky, ed., The Medici Codex of 1518 (Chicago and London, 1968), in Journal of the American Musicological Society XXXIII/3 (1980), 583 n. 12 and 587 .

16 Lockwood, "Jean Mouton and Jean Michel," p. 235 n. 106.

${ }^{17}$ Lowinsky, ed., The Medici Codex, III, 53, describes the figure as "consisting of three arrows."

18 Ibid., $53,5^{6-58 .}$

19 Ibid.

20 Ludwig Finscher, "Der Medici-Kodex-Geschichte und Edition," Die Musikforschung XXX (1977), 477-78. 
the page, and its location within the manuscript, appears to be an integral part of the codex.

The index, folios IV'-VI, exhibits features that I interpret as comprising three layers of compilation. First, the scribe ruled the paper for the index and inscribed the initials, six to the page. Several initials remain with no works listed beneath them, indicating that the symmetrical layout was prepared before the main work of copying began. Second, the scribe entered the works in the index as they were copied. This is shown by changes in hand and ink among the entries. The index lists works by title, followed by the letter 'c' (carta) and a short line to connect with the folio number along the right-hand rule of each column. Index numbers refer to the verso side of the folio, where works actually begin, not the more usual recto side. With some exceptions (discussed below), the works are grouped under each letter in order of appearance. Third, after the main corpus of music was copied, the scribe decided to add the names of composers between the titles and the page numbers. This is shown under the letter " $O$ " by the lines that are visible beneath the names "Renaldo" and "Jachet." It is also demonstrated by the cramped handwriting, which is rounder 96 than that used to record the incipits. The ink on occasion is lighter (or darker) than the incipit and the corresponding folio number. The scribe appears to have had a problem with spacing because of the letter "c" (carta); for example, under the initial "D" he erased the "c" twice. Under "S", he incorporated one "c" by turning it into a capital letter ("Carpentras"), and another by surrounding it with a large capital ("P molu"); this procedure is repeated elsewhere. The problem was most acute with the letter "I," because of the long titles. Here, the composers' names for six works appear in the margin, to the left of the incipits.

At the same time as he prepared the index (layer one), the scribe apparently ruled and numbered folios 1-202: these features remain uniform throughout the manuscript. More important, the music is copied without regard to gathering structure, so that the book was likely prepared and tied with a preliminary binding before copying began. Irregularities in the order of page numbers in the index, stemming from the second layer of index compilation, yield clues as to the order of copying. From the darkness and thickness of the ink, character size, position, and orthography, it is clear that three consecutive Masses, on folios 131'-168, were entered into the index simultaneously, as were the next three entries under " $M$," the Magnificats on folios $190^{\prime}-196$ and $197^{\prime}-200$. These six entries have the further distinction of incorporating the composers' names in the titles, for example, "messa đ brumel." After the six index entries follow a motet by Lupus (ff. 128'-129), the Missa "de Benedictus" by Renaldo (ff. 
$176^{\prime}-85$ ), and a second motet by Lupus (ff. 130'-31). The circumstances suggest that both the Masses and the Magnificats were copied "out of sequence," leaving space for additional motets before the first Mass. The space between the Mass and Magnificat groups (ff. 155'190) was filled with two Kyrie-Gloria pairs, the fourth Mass, and three more motets. ${ }^{21}$ At the beginning of the main corpus, the first three "Fors seullement" settings, on folios 1 ' -4 , also were set down together in the index, but the fourth one, on folios $9^{\prime}-11$, was entered later. Thus, by setting out important groups of compositions, the scribe demarcated the main sections of the manuscript.

Another composition that appears in the index out of numerical order is the anonymous motet "O rex gentium" (ff. 201'-202). The entry is followed by "O gemma clarissima" (ff. 109'-110) and "O dulcis amica Dei" (ff. $110^{\prime}-11$ ). "O rex gentium" is significant because it is the last work in the main body of the manuscript. Its early entry left a space of one opening between the second and third Magnificats (ff. $196^{\prime}-97$ ), and between the third Magnificat and "O rex gentium" (ff. 200'-201). These two openings each eventually received an untexted secular song, an otherwise anomalous feature that becomes more understandable if seen as filler material. ${ }^{22}$

One of the first writers to comment on the provenance of $Q 19$, Knud Jeppesen, suggests that the first motet in the collection, "Angele Dei," is a dated holograph, and that the scribe is Sebastiano Festa. ${ }^{23}$ He later adds that the manuscript was probably compiled in the region of Emilia Romagna. Lowinsky alters this thesis, and offers the opinion that $Q 19$ was compiled not by Sebastiano, but Costanzo Festa, and in France, where it was acquired by Diane de Poitiers. ${ }^{24}$ Later writers have tended to agree with Jeppesen on the provenance of the manuscript, but attack his, and especially Lowinsky's, hypotheses concerning the scribe as being unsubstantiated.25 Leeman Perkins's comment that "the manuscript may have originated in that section of the northern Italian plain in which Modena, Ferrara, and Mantua are located," perhaps best represents the scholarly consensus. ${ }^{26}$

21 The Kyrie-Gloria pairs, as it turns out, are the only works in the main corpus that are not entered in the index.

${ }_{22}$ "Cella sans plus," by Rigamundus and "Le villam jaloix," by Mouton. The former song presents a particularly crowded appearance. See also note 61 , below.

${ }^{23}$ Knud Jeppesen, ed., Italia Musica Sacra, 3 vols., (Copenhagen, 1962), I, xi.

${ }^{24}$ Lowinsky, ed., The Medici Codex, III, 57-59.

${ }^{25}$ See David Crawford, "A Review of Costanzo Festa's Biography," Journal of the American Musicological Society XXVIII/1 (1975), 105-08 and 108 n. 27.

${ }^{26}$ Leeman Perkins, Review of Edward E. Lowinsky, ed., The Medici Codex of 1518, 3 vols. (Chicago and London, 1968) in The Musical Quarterly LV/2 (1969); cited in Lockwood, "Jean Mouton and Jean Michel," 235. 


\begin{tabular}{|c|c|c|}
\hline \multicolumn{3}{|c|}{ Composers Prominent in Bologna $Q 19^{27}$} \\
\hline Composer & $\begin{array}{c}\text { Number } \\
\text { of } \\
\text { Works }\end{array}$ & Biography \\
\hline Mouton & 14 & $\begin{array}{l}\text { Chapel of Anne of Brittany, c. 1502-14 } \\
\text { French Royal Chapel, } 15^{1} 4^{-22} \\
\text { Ferrara and Bologna, Dec. } 15^{15}\end{array}$ \\
\hline Renaldo & 11 & d. Padua, Jan. $15^{21}$ \\
\hline Jacquet & 7 & $\begin{array}{l}\text { Ferrara, } 15^{16-J a n . ~} 15^{17} \\
\text { Spilamberto (near Modena), c. } 15^{17} \\
\text { Rome, } 15^{1} 9^{-20} \\
\text { Ferrara, } 15^{2} 4^{-2} 5\end{array}$ \\
\hline C. Festa & 5 & $\begin{array}{l}\text { Ferrara, March } 15^{15} \\
\text { Ischia, c. } 15^{1} 5^{-1} 7^{-1} \\
\text { Rome, } 15^{1} 7^{-45}\end{array}$ \\
\hline Lupus & 5 & Ferrara, $15^{18-19}$ \\
\hline Moulu & 5 & $\begin{array}{l}\text { Meaux? } 15^{0} 5^{-1} 5^{13} \\
\text { French Royal Chapel? c. } 15^{14^{-17}}\end{array}$ \\
\hline A. Brumel & 3 & Ferrara, $1506-10$ \\
\hline S. Festa & 3 & $\begin{array}{l}\text { Rome, } 15^{20} \\
\text { d. Rome, } 15^{24}\end{array}$ \\
\hline Maistre Jhan & 3 & $\begin{array}{l}\text { Ferrara, } 15^{12-c .} 1543 \\
\text { Padua, Sept. } 15^{17}\end{array}$ \\
\hline Richafort & 3 & $\begin{array}{l}\text { Chapel of Anne of Brittany, c. } 15^{09-14} \\
\text { French Royal Chapel, c. } 15^{1} 4^{-16} \\
\text { Bologna, Dec. } 5^{1} 5\end{array}$ \\
\hline A. de Silva & 3 & $\begin{array}{l}\text { Rome, c. } 15^{19-22} \\
\text { Mantua, } 15^{22}\end{array}$ \\
\hline Willaert & 3 & $\begin{array}{l}\text { Ferrara, July } 15^{1} 5^{-O c t . ~} 15^{17} \\
\text { Hungary, Oct. } 15^{17^{-1}} 5^{19} \\
\text { Ferrara, } 15^{1} 9^{-2} 7^{1}\end{array}$ \\
\hline
\end{tabular}

${ }^{27}$ Table II is compiled from the following sources, ordered by composer: (1) Mouton: Howard Mayer Brown, "Mouton, Jean," The New Grove Dictionary of Music and Musicians, 20 vols., ed. Stanley Sadie (London, 1980), XII, 657; Lockwood, "Jean Mouton and Jean Michel," $211-14$ (2) Jacquet: Lockwood, op. cit., 228, 232-33 (3) C. Festa: Crawford, "A Review of Costanzo Festa's Biography," 108; Lockwood, op. cit., 230; Alexander Main, "Festa, Costanzo," The New Grove VI, 501 (4) Lupus: Lockwood, op. cit., 199 (5) Moulu: Howard Mayer Brown, "Moulu, Pierre," The New Grove XII, 653; Richard Sherr, "The Membership of the Chapels of Louis XII and Anne de Bretagne in the Years Preceding their Deaths," Journal of Musicology, VI/1 (1988), 81-82 (6) A. Brumel: Barton Hudson, "Brumel, Antoine," The New Grove III, 378 (7) S. Festa: Alexander Main, "Festa, Sebastiano," The New Grove VI, $5^{\circ} 4$ (8) Maistre Jhan: Lockwood, op. cit., p. 23o, and 230 n. 91; George Nugent and James Haar, "Maistre Jhan," The New Grove XI, 541; see also p. 105, below; (9) Richafort: Howard Mayer Brown, "Richafort, Jean," The New Grove XV, 839; Sherr, "The Membership of the Chapels," $77-78$ (10) A. de Silva: Winfried Kirsch, "De Silva, Andreas," The New Grove V, 389 (11) Willaert: Lewis Lockwood; "Adrian Willaert and Cardinal Ippolito I d'Este: New Light on Willaert's Early Career in Italy," Early Music History V (1985), 85-91. 
Most scholars have also agreed that the manuscript is the work of an Italian scribe. Besides the date on the opening verso, the composers' names are given Italianate spellings, such as "Motun" and "Meter Iam." The Latin orthography also tends toward Italian. On the other hand, the little French that does appear does not fare very well, such as the Antonio Divitis "Fours seullement" on folio 9 verso.

The Venetian watermark of the main paper also suggests an Italian origin, and more likely than not, northern Italy. Much of the evidence pinpointing the exact provenance, however, derives from the character of the repertoire. Table 2 shows the most important composers in $Q 19$ in order of their total number of compositions, as well as their whereabouts in the period $15^{10-1} 5^{2} 5$. There are a total of twenty-nine known composers represented in $Q 19 .{ }^{28}$ The composer with the greatest number of works is a Frenchman, Jean Mouton, a fact that was used by Lowinsky to bolster his claim of French provenance. ${ }^{29}$ More recently, however, Lewis Lockwood has demonstrated how quickly, and with what success, French music, and especially Mouton's music, circulated in Italy in the second decade of the sixteenth century. $3^{\circ}$ That he is the best represented composer in the manuscript should therefore come as no surprise, since he was widely considered the greatest composer of the day. Furthermore, he very likely visited both Ferrara and Bologna when the French Royal Chapel accompanied Francis I to Italy in December $1515^{31}$ Another French composer, Richafort, is also presumed to have been present at the Concordat between Francis I and Pope Leo X..$^{2}$

Of the other ten composers listed in Table 2, nine are known to have resided in Italy during the period $1510-15^{2} 5$. Ferrara looms as the most important musical center represented in the manuscript, since Jacquet, Lupus, Brumel, Maistre Jhan, and Adriano Willaert all were employed by Ferrarese patrons; Mouton and Costanzo Festa also visited there. 33

Among the seventeen composers who are less well-represented in $\mathrm{Q} 19$, the pattern of north Italian connections is also strong. Of par-

${ }^{28}$ For a complete list, see Owens, Introduction, v. The unidentified composer "Remi" might be the Petro-paulo Mastaing de Remigius who was a singer in the Papal Chapel in $1496-98,1509,1513$, and possibly 1518 . See Richard Sherr, The Papal Chapel ca. 1492-1513 and its Polyphonic Sources (Ph.D. dissertation, Princeton University, 1975), 60 .

${ }^{29}$ Lowinsky, ed., The Medici Codex III, 57-58.

$3^{\circ}$ Lockwood, "Jean Mouton and Jean Michel," 193-246.

31 Ibid., $211-14$.

${ }^{2}$ Brown, "Richafort, Jean," The New Grove XV, 839.

33 See the information summarized in Lockwood, "Jean Mouton and Jean Michel," 238 . 
ticular interest are the native Italian composers Symon Ferrarensis, who served at Ferrara from $15^{1} 5^{-1} 5^{24}$, and Jacomo Fogliano, who was organist at Modena Cathedral from 1504-1548. The older composers Josquin des Près and Alessandro Agricola, who resided in Italy for lengthy periods of time, are represented by one composition each (the latter, by an unicum). Three other composers also worked in Ferrara in the first decade of the sixteenth century: Antoine de Longueval (1503-1505), Jean L'heritier (1506-1508), and Antoine Bruhier (1506-1508). Carpentras was in Rome from 1508 . In sum, at least seventeen of the twenty-nine composers represented in $Q 19$ were employed by Italian patrons at one time or another.

The choice of Ferrara or another north Italian musical center as the likely provenance of $Q 19$ has been stymied by the fact that the best represented composer, after Mouton, is Renaldo. His eleven compositions number three fewer than Mouton's, including two Masses and two Magnificats. They cover thirty-five openings, to twenty-seven for the French composer. Renaldo's music received a very limited distribution. The Census-Catalogue lists only one work by Renaldo that does not appear in $Q$ 19, the motet "Tristitia vestra 100 convertetur" in Florence, Biblioteca Nazionale, MS Panciatichi 27.34 The known concordances to works by Renaldo in $Q 19$ are "Paradisi portas," in Verona, Biblioteca Capitolare MS DCCLX, attributed to Lupus; "Regina coeli," in Padua, Biblioteca Capitolare MS A 17; and the "Magnificat quarti toni," in Bologna, Basilica San Petronio MS XXXXVI, as well as in a Scotto print of 1555 , where it is attributed to Domenico Phinot. 35 The paucity of concordances furnishes a valuable clue, since the compiler of $Q 19$ apparently had direct access to Renaldo's works.

The speculation concerning Renaldo has centered on two figures: one, mentioned by Gustave Reese, worked in Treviso, Padua, Ferrara, and the Papal Chapel between 1471 and $1493.3^{6}$ The dates are too early for Q 19 and for all but one of the concordances (Panciatichi 27, where Renaldo appears in prevailingly older company). This musician, moreover, is called "francigena," "de Odena," or "Honderic," which Lockwood interprets as "from Audenarde." 37

${ }^{34}$ University of Illinois Musicological Archives, Census-Catalogue, I-V.

35 Winfried Kirsch, Die Quellen der mehrstimmigen Magnificat-und-Te DeumVertonungen (Tutzing, 1966), 191, 385 .

${ }^{36}$ Gustave Reese, Music in the Renaissance (New York, 1954), 220.

37 Lockwood, "Jean Mouton and Jean Michel," 237. 
TABLE 3

\section{Principal Concordances to Bologna Q 19}

Manuscript or Prints

Padua, Biblioteca Capitolare, MS A 17

Motteti (Antico), RISM 1520/1,

$15^{20 / 2}, 15^{21 / 3}, 15^{21 / 5}$

Bergamo, Biblioteca Civica, MS 1209 D

Florence, Biblioteca Medicea

Laurenziana, MS Acquisti e doni 666

"Medici Codex"
Number of
Concordances

Provenance or

Place of

Publication

$11 \quad$ Padua

$10 \quad$ Venice

10 Bergamo

$7 \quad$ Rome

A different Renaldo, who died at Parma in 1529, was also French ("Renaldo francigene"), and the father of Ernoul Caussin, who was himself trained at Hainaut ("musicus gallus hannonensis"). $3^{8}$

Another Renaldo, however, appears in the chapter records of the Cathedral of Padua:

... officium Cantorie ecclesie paduane nunc per obitum vener. viri

Domini presbiteri Petri de Renaldis dicti officij vltimi possessoris, etc. cum dictum officium Cantoris die noctuque assiduum esse debeat, considerantesque vitam sufficientiam et mores vener. D. presb. Marci Badia dicte eccl. pad. capellani etc. 39

The notice is dated January $13,15^{21}$, far closer to the date of record for $Q 19$ than the dates for either of the musicians discussed previously.

The duties of the "officium Cantoris" referred to in the Chapter records were divided between two men, as often happened in late medieval Italy. The dual office was described as early as 1399 and confirmed by a papal bull of 1439, which concerned the musical organization of Padua Cathedral and provided benefices for both cantors. $4^{\circ}$ (A separate bull of 1438 provided for the board and training of eight choirboys from the city. $)^{4}{ }^{1}$ One cantor, the maestro di grammatica,

$3^{8}$ N. Pelicelli, "Musicisti in Parma nei sec. XV-XVI," Note d'archivio VIII/1 (1931), $141 ; \mathrm{VIII} / 3$ (1931), 197.

39 Raffaele Casimiri, Musica e musicisti nella Cattedrale di Padova nei sec. XIV, XV, XVI: Contributo per una storia (Rome: Edizione "Psalterium," 1942; originally published as "Musica e musicisti nella Cattedrale di Padova," Note d'archivio XVIII (1941), 1-31, 101-214, 122 .

$4^{\circ}$ Ibid., 74 .

$4^{1}$ Ibid., 186. 
normally referred to as the magister chori or regens chori, had responsibility for training the boys in plainchant, and particularly, as his title suggests, in Latin. The other cantor, the maestro di canto or magister cantus, had responsibility for teaching figured music, and for supervising the performance of polyphony. Petrus de Renaldis was magister chori at Padua Cathedral, a position that would have afforded ample opportunity for the composition of polyphony. $4^{2}$ It was an important position, symbolized by the staff of office that was carried in processions: in ${ }^{1} 5^{1} 5$, the silver bachulum pertaining to the magister chori was fractured and was ordered to be repaired.43

The composer Renaldo, then, held a clerical benefice at the Cathedral of Padua during the period in which Q 19 was compiled, and Padua is therefore the most likely provenance for the manuscript. Some strong corroborating evidence supports this contention. In the first place, the manuscript contains motets dedicated to the two principal patron saints of the city: "Veni sponsa Christe" (ff. $35^{\prime}-36$ ) is addressed to St. Justina, and "Ecclesiam tuam" (ff. 26'-28) is an oration for the Proper of St. Anthony of Padua. "Veni sponsa Christe" is an anonymous work that is shared by at least one other manuscript102 Bologna, Civico Museo Bibliografico Musicale, MS R 142, a source compiled in the Veneto. "Ecclesiam tuam" is one of two unica attributed to Jacquet in $Q 19$, raising the possibility that he had some connection with Padua during the second decade of the century. Such a connection would explain why "Ecclesiam tuam" appears within a series of ten motets by Renaldo and Jacquet near the beginning of the manuscript, folios 15 ' -38 , interrupted only by "Veni sponsa Christe" and single motets by Mouton and Maistre Jhan. The last two motets of the series, in fact, are paired settings by Renaldo and Jacquet of the text "O Jesu Christe miserere mei."

A different category of evidence, one that has not been employed heretofore, also supports Padua as the place of origin for the codex. Of the three manuscripts that have the most concordances with $Q 19$, two are from the Venetian terra ferma, and the third is Roman (Table 3). The greatest number of concordances, eleven, is shared with Padua, Biblioteca Capitolare MS A 17.44 This manuscript was compiled by Giordano Passetto for the Cathedral of Padua, and is dated 1522. Bergamo, Biblioteca Civica MS 1209 D was compiled for the

$4^{2}$ Ibid., $5^{6 .}$

43 Ibid., 118.

44 The converse is also true; Padua A 17 has more concordances with Bologna $Q$ 19 than with any other source. 
cathedral in Bergamo, but is later, circa $15^{2} 5^{-5} 5^{0.45}$ The Antico motet books were published in Venice in 1520-21 and reflect a repertory that was in general circulation at the time. $4^{6}$

Of the eleven concordances between Padua A 17 and Bologna $Q$ 19 , four works are unique or are shared by but one other source. 47 The surprisingly high percentage of works with limited distribution suggests a close relationship between the two manuscripts and lends further support to Padua as the place of origin for the codex. The composers of the four works in question are Costanzo Festa, Jacquet, Renaldo, and Mouton. $4^{8}$ In addition, another Jacquet motet has concordances with Padua, Biblioteca Capitolare MS D 27, and Bergamo 1209 D.49 This brings to four the number of Jacquet motets that are either unique to $Q 19$, or are shared with manuscripts of known Paduan provenance. A fifth motet, "Sufficiebat nobis" (ff. $32^{\prime}-35$ ), is known from a manuscript, now destroyed, compiled in nearby Treviso. $5^{\circ}$

Renaldo himself is identified as the scribe and compiler of $Q 19$ by the initials "D P"-Dominus Petrus-near the beginning of the manuscript..$^{1}$ The iconography of the monogram lends the identification a high degree of probability. The barbed cross, or cross barbée, is a

45 University of Illinois Musicological Archives, Census-Catalogue I, 35 and IV, 249-50. The manuscript transmits a retrospective repertoire, and may have been copied in part from an older source.

$4^{6}$ See also Martin Picker, ed., The Motet Books of Andrea Antico (Chicago and London, 1987), published as vol. VIII of Monuments of Renaissance Music, 8 vols. to date, ed. Howard Mayer Brown, 3-4, 6-7.

${ }^{7} 7$ The Mouton motet, "Alleluya, confitemini Domino," ff. 185 ' -86 , has a second part (so labelled), "Stetit Jesu in medio discipulorum," on ff. 101'-102. Both parts of the motet are found in Padua A 17, where they likewise are copied separately, but without a connecting rubric. If the two partes of the motet are counted individually, the number of works shared between the manuscripts comes to twelve. Both partes are also found in Vienna, Österreichische Nationalbibliothek MS 18825 , where they are copied twice, as well as in RISM $\mathbf{1 5 4 5} / \mathbf{2}$. The latter is not taken into account here because of its substantially later date. See John G. Constant, Renaissance Manuscripts of Polyphony at the Cathedral of Padua (Ph.D. dissertation, University of Michigan, 1975), 72.

$4^{8}$ Festa, "Regem archangelorum," ff. 11 1'-12, Jacquet, "Veni Sancte Spiritus," ff. $21^{\prime}-22$, Renaldo, "Regina coeli/Sancte Maria," ff. 30'-32, and Mouton, "Alleluya, confitemini Domino," cited in note 47.

49 "Noe, noe, hodie Salvator mundi natus est," ff. 15 '-17.

$5^{\circ}$ George Edward Nugent, The Jacquet Motets and their Authors, 2 vols. (Ph.D. dissertation, Princeton University, 1973), I, 151 .

${ }^{51}$ Ottaviano Petrucci's Frottole Libro Undecimo (RISM 1514/2) provides an example of this sort of initial. "Che faralla," f. 28 , is attributed to "D. M." which stands for the composer Don Michele Pesenti. The following work, f. 29, is similarly attributed to "D. Timotheo." 
representation of the fish hook, symbolizing "the fisher of men" (Matthew 4:19)..$^{2}$ The unusual shape of the cross results from two symbols frequently used in combination: the diagonal arms of the cross represent the two keys of St. Peter, in saltire, while the horizontal base (between the initials) and vertical line arising from it represent the upside-down cross on which the apostle is said to be have been crucified.53 Thus the monogram unites three symbols of St. Peter, together with the initials, in a single personal emblem.

Renaldo's music is broadly representative of the kinds of texts found in the manuscript as a whole, and is strategically placed within the manuscript. The first Mass is by him, as are the first two Magnificats, both within groups that were copied out of sequence. A Missa "de Benedictus" by Renaldo was copied later, also out of sequence. His motets are entered in the first quarter of the main corpus. Two motets, "Paradisi portas" and "Haec dies," set texts for specific liturgical occasions, namely, the first Sunday in Lent and Easter Week. "Illuminavit eum" employs the collect for the Proper of St. James the Apostle, and stands at the head of the series of orationes mentioned previously (page 94).54 The Cathedral of Padua is dedicated to the 104 Virgin Mary, and two of Renaldo's motets are for the Virgin, "Regina coeli/Sancte Maria," and "Ave sanctissima Maria." They are among ten works in Q 19 addressed to the Virgin. 55 "O Domine Jesu Christe" is a version of one of the Prayers of St. Gregory and was said as part of the Hours of the Sacred Cross. $5^{6}$ The prayers were believed to grant large indulgences when recited before Mass. 57 It is worth noting that the Cathedral had an altar of the Sacred Cross, near the great crucifix, that was much venerated in the Middle Ages..$^{8}$ Renaldo's setting is homophonic and recalls the polyphonic lauda. Besides the

$5^{2}$ F. R. Webber, Church Symbolism, 2nd ed. (Cleveland, 1938), 111.

53 Ibid., 194-95.

54 Folios $23^{\prime}-25$; it is preceded in the index by Andreas de Silva "In illo tempore loquente Jesu ad turbas," ff. $44^{\prime}-45$, which is the first work listed under "I", and succeeded by Sebastiano Festa, "In illo tempore postquam consumati," ff. 62' -63 .

55 Lowinsky, "On the Presentation and Interpretation of Evidence," p. 123 and 123 n. 62, numbers eleven motets. I do not include "Nobis Sancte Spiritus," ff. 4'-5, since it is called a hymn for the Hours of the Holy Ghost in Alexandri Agricola, Opera Omnia, 5 vols., ed. Edward R. Lerner (American Institute of Musicology, 1961-70) IV, xi.

$5^{6}$ E. S. Dewick, ed., Facsimiles of Horae de Beata Maria Virgine from English MSS. of the Eleventh Century (London, 1902), columns 45, 61-62.

57 Antonii Brumel, Opera Omnia, 6 vols., ed. Barton Hudson (American Institute of Musicology, 1969-72), V, xxxix. Brumel's “O Domine Jesu Christe," ff. 93'-94, sets one of the same series of prayers.

${ }_{5}^{8}$ Giulio Bresciani Alvarez, "La Cattedrale," Padova: basiliche e chiese, 2 vols., ed. Claudio Bellinati and Lionello Puppi (Vicenza, 1975), I, 84. 
Cathedral, the only other establishment in Padua known to have performed polyphony at this period was the Basilica di San Antonio, called the Santo. The motet "Tristitia vestra," in Panciatichi 27, is a responsory from the Office of Saints Philip and James, and is addressed to St. James the Lesser. It could have been performed in the Cappella Luca Belludi of the Basilica di San Antonio, a small chapel dedicated to Saints Philip and James.59

With respect to the large number of Ferrarese composers represented in $Q 19$, one should keep in mind the importance of Ferrara as a center of north Italian musical patronage. It is not surprising that a manuscript from a less affluent center such as Padua would reflect Ferrarese preeminence. One known work was, in fact, commissioned by Padua from a Ferrarese composer. A motet by Maestre Jhan in Bologna, Civico Museo Bibliografico Musicale, MS Q 20, a source compiled in northern Italy, probably in the 1520 , begins "Ave gloriose beatissime Antoni, ora pro populo tuo patavino."6o The explicit mention of Padua in a motet dedicated to its patron saint betokens a definite cultural exchange between Padua and Ferrara and also shows that similar commissions could have been undertaken by Jacquet, who had strong Ferrarese connections.

One way in which works such as "Ave gloriose beatissime Antoni" circulated is shown by the visit of Maistre Jhan to Padua on September $28,15^{17}$, as recorded by the historian Giannantonio Corte:

Vene in questa terra uno certo meser Jan franzese era maystro de capella del duca de Ferara et cercha de straviar uno nostro zago Sandreto Cantava bene; le promese assay cosse; era tutto lochio de messer Rufino. Si ge lo meno via de questa terra. Feno male. Havea una chierega. ${ }^{61}$

The Sandreto mentioned in the entry was probably a choirboy, as indicated by the diminutive form of his name, and the fact that no Sandreto is mentioned among the regular Cathedral singers of the time. That Maistre Jhan tried to lead him astray ("straviar") - to recruit him for the ducal chapel-was not appreciated by his counterpart, Fra Rufino Bartolucci, who by all accounts was an excellent maestro di canto. Nevertheless, Maistre Jhan presumably arrived with

59 Leonello Puppi, "La Basilica del Santo (con l'Oratorio di S. Giorgio e la Scoletta del Santo)," Padova: basiliche e chiese, 2 vols., ed. Claudio Bellinati and Lionello Puppi (Vicenza, 1975), I, pp. 189-9o and 19o n. 71.

6o Johannis Lhéritier, Opera Omnia, 2 vols., ed. Leeman Perkins (American Institute of Musicology, 1969), I, xl.

6. Antonio Sartori, Documenti per la storia della musica al Santo e nel Veneto, ed. Elisa Grosato (Vicenza, 1977), 10. 
examples of his own music, which could have been obtained sometime before he was asked to leave the city.

The purpose of $Q 19$ appears to have been to record an accumulated store of music and to serve as a repository for new repertoire. Functional, moreover, would seem to be the key word in describing the book, from its dimensions, 291 by 228 millimeters, large enough to be read by a small group of singers, to its modest calligraphy. ${ }^{62}$ While the manuscript may have been intended for the private use of the scribe-Lewis Lockwood suggests that most musicians probably kept a similar record-its great volume may indicate that it was compiled for use within an institution. ${ }^{6}{ }_{3}$ Jessie Ann Owens notes that the contents, which represent various feasts and occasions throughout the year, also are appropriate to the needs of an institution. ${ }^{64}$ It could have been employed as a source from which additional copies were made, or it could have been used in performance.

The dating of $Q 19$ remains a thorny problem. Although the recorded date, on folio I verso, is in the same hand as the rest of the manuscript, there is a question as to what it represents, particularly since the first two original folios (I-II) are separate from the rest of the manuscript and have a different watermark. It is possible that "Angele Dei" was copied on a detached bifolium and later inserted in the manuscript. It could represent a dated letter that the scribe added to the collection. It seems more likely, however, that "Angele Dei" was copied under the same circumstances as "Moriens lux amatissima," on folios III'-IV (see Table 1). ${ }^{6}$ Both motets appear prior to the manuscript index - an unusual position - both are ruled freehand, and, like the other works copied in the scribe's second manner, they are not listed in the index. It may be that the "extra" folios, I-II and [203], were added at the time of binding, after the main corpus was finished. The scribe had more works to copy, and placed them where he could. As a consequence, nearly all the available space in the manuscript is filled with additional music. ${ }^{66}$ This explains why none of the pieces

62 Owens, Introduction, vi.

${ }^{63}$ Lockwood, "Jean Mouton and Jean Michel," 228-29.

${ }^{6}$ Owens, Introduction, v.

${ }^{6} 5$ See also Staehelin, Review, p. $5^{8} 3$ n. 12.

66 The works at the end of the manuscript constitute true addenda. The canon "Chimer chiner" (f. 202') is a canto dei lanzi, satirizing the German Landsknechte. (See Ludwig Finscher, "Der Medici-Kodex," p. 478 n. 34.) "Beata Apollonia" (ff. 202'[203]) addresses the patron saint of dentists. These latter works are the only ones in $Q$ 19 that share an opening. The last page, [203]', presents the missing voices for two motets copied earlier in the codex, and consequently succeeds the main work of copying. At the top of the page is the bass part for Moulu's "O dulcis amica Dei" (ff. $110^{\prime}-11$ ). Below it is the second tenor for the Rigamundus "Cella san plus," (ff. 196'97). This part is duplicated across the bottom of the original opening, employing a 
outside the main corpus appears in the index. It also explains why new staff lines were copied freehand; since the binding was still fresh, it was not possible to use a rastral. Indeed, the staff lines show an upward arch that may have resulted from the natural curvature of the bound leaves. The exception, "Jay" (folios VI'-1), was copied on the opening between the preliminary gathering and the first main gathering.

It now appears unlikely that Sebastiano Festa, whose patron had business primarily in Rome, had anything to do with the compilation of $Q$ 19. It could be that the date, as Lowinsky argues, represents the date of completion of the manuscript, specifically of the addenda. On the other hand, the date at the head of "Angele Dei," because of its close conjunction with Festa's name, may refer to the composition of the motet. ${ }^{6} 7$ Moreover, the significance of its placement on the first page of the codex should not be overlooked. It has a semiotic value, particularly in view of the uneven appearance of the preliminary folios, which in effect violates the scribe's original intention. This consideration would indicate that the manuscript was completed not long after the inscribed date, and probably in 1518 . As to the date of inception, an estimate that the codex took some three years to compile appears sound, and suggests a starting date of ${ }_{15}{ }^{16.68}$ An inception date of ${ }_{15} 16$ agrees with the likely date of the principal watermark $(1514)$. The two ceremonial motets with secure dates (Bruhier, "Vivite felices," December ${ }_{15}^{15}$, and Costanzo Festa, "Quis dabit," ${ }^{15}{ }^{14}$ ) likewise provide a reference point for the inception of the codex. ${ }^{69}$ At least two of the composers represented in $Q$ 19, Symon Ferrarensis and Adrian Willaert, did not begin their Italian careers until ${ }_{15}^{15}$, and their music would not have immediately circulated. A ${ }_{15}^{16-15^{18}}$ frame for $Q 19$ also agrees with the principal concordances, which are dated 1518 at the earliest.

smaller rastral than normal. Its appearance there may consequently represent an afterthought on the part of the scribe.

${ }^{67}$ In the year ${ }_{15} 18$, June 10 was the octave of Corpus Christi, a day not associated with the guardian angel, to whom Festa's motet is addressed. The date is therefore unlikely to refer to a performance of the motet.

68 Lowinsky, "On the Presentation and Interpretation of Evidence," 124 , suggests the dates $15^{1} 5^{-1} 8$ for Bologna Q 19 ; he is cited in Lockwood, "Jean Mouton and Jean Michel," p. 240 and $240 \mathrm{n}$. 116. A yardstick for how long might be required to compile a manuscript of this size is provided by Padua $\mathrm{A}_{17}$, which is of approximately the same length, though more elaborate. The scribe, Giordano Passetto, was hired as maestro di canto in Padua March 16,1520 , and the manuscript is dated $15^{22}$. See Casimiri, Musica e musicisti nella Cattedrale di Padova, 120-21.

${ }^{69}$ Lowinsky, "On the Presentation and Interpretation of Evidence," 124. The Bruhier motet is an unicum; Festa's motet has a concordance in Milan, Biblioteca Ambrosiana, MS Trotti 519 , ff. $15^{\prime}-16^{\prime}$. 
Identification of the Paduan provenance of $Q 19$ has the potential to clarify the history of the first two decades of the sixteenth century in several respects. Renaldo, whose name appears so prominently in the manuscript (spelled several different ways) may be identified with the Petrus de Renaldis who was magister chori at the Cathedral of Padua, and who died in $15^{21}$. He is most probably the scribe of $Q 19$ and may have compiled it for an institution, perhaps the Cathedral of Padua. The heavy representation of Ferrarese composers in $Q 19$ can be attributed to the high quality of the chapels maintained there, and the ready distribution of music throughout northern Italy. The narrow distribution of five of the seven Jacquet motets, including one addressed to St. Anthony of Padua, suggests that he was commissioned to write music for Padua. Manuscript concordances and the date of copying bring $Q 19$ into the orbit of other Italian sources such as the Medici Codex and Padua A 17, affording a more exact picture of the important developments brought about by the post-Josquin generation of composers of sacred music in Italy. 